\title{
舌可動部癌の治療成績
}

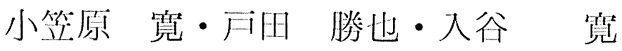 \\ 兵典子・雲井 健雄
}

\section{Treatment of Carcinoma of the Mobile Tongue}

\author{
Hiroshi Ogasawara, Katsuya Toda, Hiroshi Iritani, \\ Noriko Hyo and Takeo Kumoi \\ (Hyogo College of Medicine)
}

\begin{abstract}
Thirty-five patients with squamous cell carcinoma of the mobile tongue are reviewed. The 5-year survival rate was $86 \%$ in $\mathrm{TxNo}, 54 \%$ in $\mathrm{TxN}_{+}, 80 \%$ in $\mathrm{Tl}$, $81 \%$ in $\mathrm{T} 2$ and $50 \%$ in $\mathrm{T} 3$. The survival rate for TxNo cases was significantly higher than that for $\mathrm{TxN}_{+}$cases. Cervical node metastases was more frequently observed in patients treated by radiotherapy than in those undergoing surgery. Surgical therapy of the $\mathrm{T} 1$ lesions was found to be very effective, but radiotherapy was less successful in controlling the primary disease. In the patient with T2 lesion, surgical therapy and radiotherapy showed the same results. Frequent follow-ups should be made of the cases for early detection of control failure and salvage by aggressive surgery.
\end{abstract}

Key words: carcinoma of the mobile tongue, surgical therapy, radiotherapy, cervical metastases

はじめに

舌可動部癌の治療には，形惪抢よび情音，柤 嚼，嬩下の機能とがともに保存される放射線燎 法之，多かれ少なか机两者と屯に障管を受ける 手術療法とがある. 初划癌に対しては前者の放 射線治療によって，よく制御可能である ${ }^{112)}$ 。し かし，一方では制御失敗例の手術による salvage の成績は，手術侍期の達れや，手術による 切除範四が不充分であったりして必ずし屯战好 とはいえない. Gilbert4) や Mulholland ${ }^{5)}$ は むしろ程極的に手術を行うことによって，洲是 すべき成績をあげ得ることを報告している。ま
た組織内照射治㡜は頸部リンパ筑転移の唀因と なることが閌题である。近作皮弁や筋皮乔等老 用いる再建手術が進歩し，進行癌症例の手術屯 可能となり，機能障㫪在屯愢減する試みがなさ れている.

当施設では組織内照射ができないこと屯あ り，手術療法老第一退执することが多かった。 3 年以上経過徽察し得た 8 年間の舌嵒症例の治 療方法とその経過を検討した。

\section{対 象}

1974年より1982年の 8 年䦌に兵庫医科大学耳

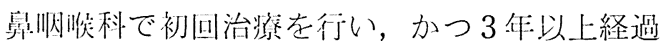


観察し得た。舌根部を除く舌可動部癌は35例で あった，男了 27 人，文子 8 人と男子症例が多か った。平均年分は 53.4 才で最年少者は28才, 最 年長者は84才であった。 T NM分類（1978年， UICC) は表 1 と 2 に示したように， $\mathrm{N}_{0} 22$ 例， $\mathrm{N}_{+} 13$ 例で， $\mathrm{N}_{+}$はすべて $\mathrm{N}_{1}$ でであった， T分類 は $\mathrm{T}_{1} 10$ 例, $\mathrm{T}_{2} 16$ 例, $\mathrm{T}_{3} 8$ 例, $\mathrm{T}_{4} 1$ 例であった。 病理組織分類は全例が扁平上:皮癌であった。

\section{治療法と予後}

舌癌の治療方釗は原則として手術療法老行う こととして，術前に外照射を $30 \mathrm{~Gy}$ 又は化学療 法を行った。手術は $\mathrm{T}_{1} \mathrm{~N}_{0} や \mathrm{~T}_{2} \mathrm{~N}_{0}$ で侵潤傾问 や進展が少ないむのには口腔からの舌部分切除 と，半数に予防的頸部郭清としてリンパ組織郭 清術を顎下部または頸部に行った。 $\mathrm{T}_{2} \mathrm{~N}_{0}$ でむ $\mathrm{T}_{3}$ に近い症例や進行例では pull through operationを在行った。
放射線療法はラジゥム針組織内照射を Paterson-Parker に従って70〜80Gy/7〜10日照 射した，腫愓が小さくて腔内照射用照射筒を設 定できる部位では電子線舩内照射を 1 回 $5 \mathrm{~Gy}$ で50〜60Gy を，そのいずれをむ実施できふい 場合には ${ }^{60} \mathrm{Co}$ または LinacX 線の外照射在行 った。

\section{$\mathrm{T}_{\mathrm{x}} \mathrm{N}_{0}$ 症例}

9 例に放射線療法を行った。ラジウム針組織 内照射は 3 例に行い， $\mathrm{T}_{1}$ 症例の 1 例は局所再発 し, $\mathrm{T}_{3}$ 症例は頸部転移が生じたが頸部郭清術で 制御した。電子線腔内照射は 4 例に行い， $\mathrm{T}_{1}$ の 1 例が局所再発し, 部分切除で制御され，また $\mathrm{T}_{1}$ の 1 例は頸部リンパ節転移が生じ，放射線と 頸部郭清術でむ制御できなかった。外照射之化 学療法之の併用は 2 例に行われ制御されてい る.

表 I $\mathrm{TxN}_{0}$ 舌可動部癌の治療法と成結

\begin{tabular}{|c|c|c|c|c|c|c|c|c|}
\hline \multirow{3}{*}{$\begin{array}{l}\text { Initial Therapy } \\
\text { Radiation alone }\end{array}$} & \multicolumn{3}{|c|}{ Local Control } & \multirow{3}{*}{$\begin{array}{l}\text { Development of } \\
\text { Cervical } \\
\text { Metastases } \\
4\end{array}$} & \multicolumn{3}{|c|}{ Cause of Death } & \multirow{2}{*}{$\begin{array}{l}\text { Total } \\
\text { Number } \\
\text { Surviving }\end{array}$} \\
\hline & $\mathrm{T}_{1}$ & $\mathrm{~T}_{2}$ & $\mathrm{~T}_{3}$ & & \multicolumn{2}{|c|}{\begin{tabular}{l|l} 
Local & Lervical \\
Failure & Failure
\end{tabular}} & \multirow{2}{*}{\begin{tabular}{|c|}
$\mid \begin{array}{l}\text { Other } \\
\text { Causes }\end{array}$ \\
1
\end{tabular}} & \\
\hline & $1 / 3$ & $3 / 3$ & $1 / 1$ & & 1 & 1 & & $4 / 7 \quad(57 \%)$ \\
\hline Radiation + Chemotherapy & $2 / 2$ & 0 & 0 & 0 & 0 & 0 & 0 & $2 / 2 \quad(100 \%)$ \\
\hline Preoperative radiation & 0 & $1 / 2$ & 0 & 0 & 0 & 0 & 0 & $2 / 2 \quad(100 \%)$ \\
\hline Chemotherapy + Surgery & $2 / 3$ & $1 / 1$ & $1 / 1$ & 0 & 0 & 0 & 0 & $5 / 5 \quad(100 \%)$ \\
\hline Surgery alone & $2 / 2$ & $1 / 3$ & $1 / 1$ & 0 & 1 & 0 & 0 & $5 / 6 \quad(83 \%)$ \\
\hline Total & $7 / 10$ & $6 / 8$ & $3 / 3$ & 4 & 2 & 1 & 1 & $18 / 22(82 \%)$ \\
\hline
\end{tabular}

表 $2 \mathrm{TxN}+$ 舌可動部癌の治療法と成績

\begin{tabular}{|c|c|c|c|c|c|c|c|c|}
\hline \multirow{2}{*}{ Initial Therapy } & \multicolumn{4}{|c|}{ Stage } & \multicolumn{3}{|c|}{ Cause of Death } & \multirow{2}{*}{$\begin{array}{l}\text { Total } \\
\text { Number } \\
\text { Surviving }\end{array}$} \\
\hline & $\mathrm{T}_{1}$ & $\mathrm{~T}_{2}$ & $\mathrm{~T}_{3}$ & $\mathrm{~T}_{4}$ & $\begin{array}{l}\text { Local } \\
\text { Failure }\end{array}$ & $\begin{array}{l}\text { Cervical } \\
\text { Failure }\end{array}$ & $\begin{array}{l}\text { Other } \\
\text { Causes }\end{array}$ & \\
\hline Radiation + RND & 0 & 2 & 0 & 0 & 0 & 0 & 0 & $2 / 2(100 \%)$ \\
\hline Radiation + Chemotherapy & 0 & 1 & 1 & 0 & 2 & 0 & 0 & $0 / 2(0 \%)$ \\
\hline Preoperative radiation & 0 & 3 & 3 & 0 & 1 & 1 & 0 & $4 / 6 \quad(67 \%)$ \\
\hline Postoperative radiation & 0 & 0 & 1 & 0 & 0 & 0 & 1 & $0 / 1(0 \%)$ \\
\hline Chemotherapy + Surgery & 0 & 1 & 0 & 0 & 1 & 0 & 0 & $0 / 1(0 \%)$ \\
\hline Chemotherapy alone & 0 & 0 & 0 & 1 & 1 & 0 & 0 & $0 / 1(0 \%)$ \\
\hline Total & 0 & 7 & 5 & 1 & 5 & 1 & 1 & $6 / 13(46 \%)$ \\
\hline
\end{tabular}


13例に手術療法を行った．2例は術前照射， 5 例は neo-adjuvant chemotherapy, 6 例は 手術単独であった。頸部郭清術は 3 例，リンパ 組織郭清術を全頸部 2 例, 顎下部 3 例に行った が，組織学的には転移在認めなかった。また初 回治療後に頸部リンパ節転移をきたした症例は なかった. 局所再発は 3 例にみられ，1例は $\mathrm{T}_{3}$ で multiple myeloma 合併例で死亡, 1 例 は $\mathrm{T}_{1}$ で 7 年後に径 $3 \mathrm{~mm}$ の白板を伴った初剘癌で レーザーで制御, 1 例は $\mathrm{T}_{2}$ で扁桃窝に再発し凍 結手術で制御されている.

\section{$\mathrm{T}_{\mathrm{x}} \mathrm{N}_{+}$症例 :}

ラジゥム針組織内照射と電子線腔内照射の备 1 例は頸部郭清と併用し制御された。放射線と 化学療法の 2 例と化学療法の 1 例は㚲息的治療 であった。手術は 8 例に行われ，2例は局所治 療に失敗，1例は頸部再発した. $53 \mathrm{~Gy}$ の後照 射在行った $T_{3}$ 症例では, 7 年後に传通癌 8 年後 に同側の扁桃癌が生じて手術にて制御したが 9 年後に反対側の扁桃癌が生じ死亡した。病理組 織は何れ屯扁平上皮癌であったが，放射線治療 が府桃嵒の誘因になったと推定された。

生存率（図 1, 図 2):

Kaplan-Meier 法により生存率を求めた. $\mathrm{T}_{\mathrm{x}} \mathrm{N}_{0}, \mathrm{~T}_{\mathrm{x}} \mathrm{N}_{+}$の 5 年生存率はそれぞれ $86 \%$ ， $54 \%$ で, $\mathrm{T}_{\mathrm{x}} \mathrm{N}_{0}$ は $\mathrm{T}_{\mathrm{x}} \mathrm{N}_{+}$より有意に生存率が高 かった $\left(\mathrm{P}<0.025, \chi^{2}\right.$-test $) . \mathrm{T}^{1}, \mathrm{~T}^{2}, \mathrm{~T}^{3}$ 症例の 5 年生存率はそ机ぞれ $80 \%, 81 \%, 50 \%$ あった。

\section{考按}

舌可動部癌の根治的治療方針として放射線治 療を主とするか，手術治療を主とするかは論議 の分かれるところである. 外照射による根治治 療には総量的に必望十分量の照射が困難なとと が多く, 照射治療の主流は小線源治療が行われ る. しかし小線源治療走行うには施設や医療從 事者の被爆の問題むあり，困難を伴う。わたし たちは施設にその設備を持たないこと屯あり, また癌に対する理念加らも手術療法を中心に行 ってきたが，舌根にまで及んでいない $\mathrm{T}_{2}$ 症例 を中心に組織内照射も行っている。既法 ${ }^{17)} の$ Cole-Engman 症候群に合例した $\mathrm{T}_{3}$ 症例では 舌根まで腫瘍が進展し，Cs 針を用いて治療し たが制御できなかった。ラジゥム針による局所 腄演制御率は $3 / 4$ (75\%), 電子線腔内照射 4 / $5(67 \%)$, 外照射 $\% 3(67 \%)$ で，合計すると放射 線治療の制御摔は 9/13(69\%)であった。局所治 療失敗 4 例のうち 1 例のみ手術により制御され た. 舌半侧切除走行った15例中 4 例は再発し, うち 1 例は二次手術にて制御された。舌部分切 除を行った 6 例中 1 例のみに再発をみたが，二 次治療に制御された。乎術方法による局所制御 率には湆は涊めず，手術方法の選抓に問題がな かったととを获づけている。手術療法の一次成 續は21例中16例（76\%）の局酒倐御摔で，放射 線療法とは厓はなかった。

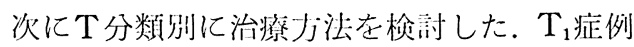

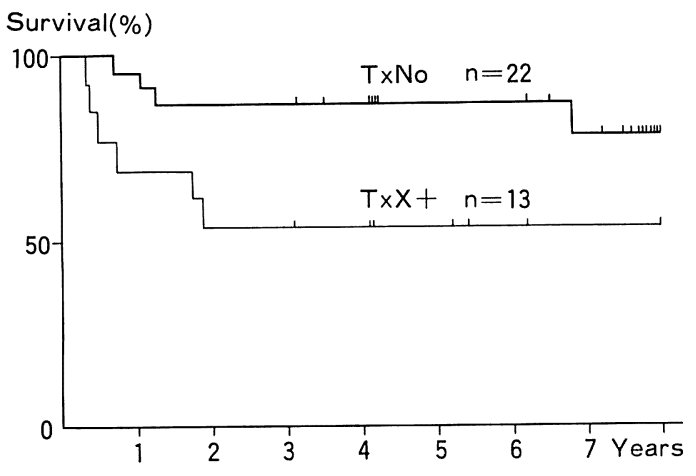

図Ｎ N分類と生存率

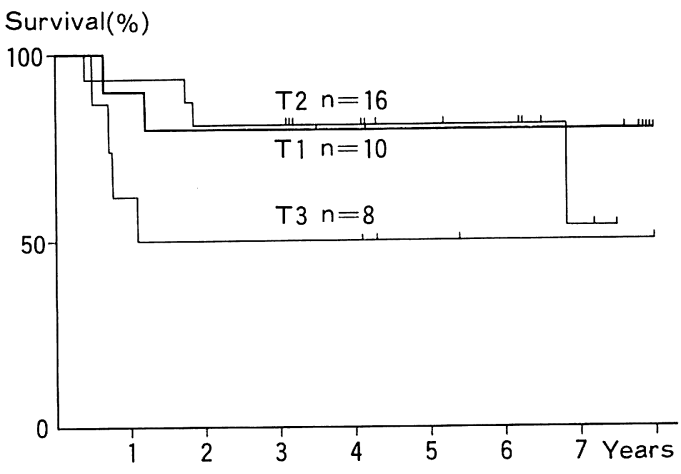

図 $2 \mathrm{~T}$ 分類と生存率 
では， 5 例に放射線療法がおこなはれ，2 例局 所再発，2例頸部転移出現した。また乎術療法 がおこなわれた 5 例中 1 例に 7 年後白板症様の 早期癌が出現したのみであった。

$\mathrm{T}_{1}$ に関しては，手術療法は局所制御率がよ く，頸部転移出現がなかった。手術は口腔より 舌部分切除術で十分で，頸部手術を侏用する場 合でむリンパ組織郭清術ですみ，手術後の機能 障害む最小限ですむ．以上のことより $\mathrm{T}_{1}$ 症例 は, Leipzig ${ }^{7)}$ や Vermund ${ }^{8}$ の報告之同様, 放射線療法上りあ手術療法が優れている.

$\mathrm{T}_{2}$ に関しては，放射線療法を行った 6 例中 5 例に局所制御が得られた。しかしてのうち電子 線腔内照射した 2 例は照射後潰煌を比成し，舌 半側切除に至った。手術療法は10例に行い， 3 例局所再発， 1 例頸部再発をきたした。雨治療 法の成績には差は認められなかったが，手術に よる機能障害は $T_{1}$ に比し大であり, 機能を重視 するならば放射線療法を第一選択にすべきと考 える. しかし最近は舌切除後の再建手術を工夫 し, 機能障害, 特に構音障害の改善に努めてい る. $\mathrm{T}_{2}$ であ半侧切除の必要な症例や $\mathrm{T}_{3}, \mathrm{~T}_{4}$ 症 例では大胸筋皮弁を用いた再建手術をし，発語 の明膫度は良好であったが，筋皮弁の容量が年 月とと屯に減少するにつれ，明膫度が低下する 場合があった 背筋皮弁を用い，明膫度の低下を防止できるか 検傠中である.

$\mathrm{T}_{3}$ に関しては， $\mathrm{N}_{0}$ 症例で屯予防的頸部郭清 をすることが多く，手術療法が中心におこなわ れた。治療成績の向上のため，外照射との併用 を 4 例に行った。進行症例に対しては，放射線 と手術との併用療法が欮独治療よりよいとの報 告が多( ${ }^{10111}$. 現在術前照射飞術前化学療法が とって代ることができるか検討中である.

$\mathrm{T}_{\times} \mathrm{N}_{0}$ で初回治療後に頸部リンパ節転移在き たしたのは，放射線治療を行った 4 例のみであ った。ラジウム針組織内照射は電子線腔内照射 より頸部リンパ節転移を誘発することが多く， それぞれの出現率は 3/3（100\%）と 1/4（25
\%）であった，治潦開始時に臨床的に頸部転移 がなく病理的検討で34\%に潜在的転移があっ た ${ }^{12)}$ との報告があり，乙れに対する対応が問題 である。予防的頸部照射が頸部リンパ節転移を 予防するという意見が多いが(1314)，5000 rad 照 射は，転移防止にならず，却って下顎骨壊死を きたすだけという意見むある ${ }^{15)}$. しかし，放射 線療法後の頸部リンパ節転移出現は予後不良 で，乙れに局所再発が後日顕著になること屯あ るため, 厳重な経過観察と早期の的確な手術が 重要である，そして積極的な手術により，再発 例は十分に制御されている(4)5.

手術治療を行った13例中 9 例に, 程度の差は あるが頸部清掃がおこなはれ，頸部りンパ節転 移出現の予防になったと推定される。しかし， Beavfr6) は頸部手術を局所治療に加えて屯, 生存率や再発率は良くならず， $\mathrm{T}_{1}$ と $\mathrm{T}_{2}$ に対し ては局所手術のみで，厳重な経過観察を 3 年間 は行う力法を述べている．以上まとめてみる 之, 舌癌の初回治療後は局所再発之頸部軽移出 現に充分注意を払い，対応を愦らないととが重 要である。

\section{まとめ}

3 年以上経過推察しえた35例の舌可動部癌の 治療成績を検討した。 5 年生存率は $\mathrm{T}_{\mathrm{x}} \mathrm{N}_{0} 86 \%$, $\mathrm{T}_{\mathrm{x}} \mathrm{N}_{+} 54 \%, \mathrm{~T}_{1} 80 \%, \mathrm{~T}_{2} 81 \%, \mathrm{~T}_{3} 50 \%$ で, $\mathrm{T}_{\mathrm{x}} \mathrm{N}_{0}$ は $\mathrm{T}_{\mathrm{x}} \mathrm{N}_{+}$より有意に昆好であった $(\mathrm{P}<0.025)$. $\mathrm{T}_{1}$ の局所治療として，放射線療法は制御率が低 く，頸部リンパ節転移を誘発することが多いた め, 軽度の機能障害のみ伴う手術療法が良かっ た. $\mathrm{T}_{2}$ の局所制御率は放射線療法と手術療法に は差を認めなかった。再発や転移に対しては笄 重な経過推察と積極的な手術による再治療が重 要である。

\section{参考文献}

1) Denham JW, Strickland P, et al : Interstitial radiation terapeutic techniques at Mount Vernon Hospital. Acta Radiologica Oncology 21:385 392, 1982.

2) Decroix $Y$ and Ghossein $\mathrm{N}$ : Experience of 
the Curie Institute in treatment of cancer of the mobile tongue. Cancer $47: 496 \sim 502$, 1981.

3）藤谷哲造, 服部 浩, 他：舌癌局所再発症例に関 する臨床的検討. 耳诶 $48: 51 \sim 56,1976$.

4) Gilbert EH, Goffinet DR and Bagshaw MA : Carcinoma of the oral tongue and floor of mouth: Fifteen years experince with linear accelerator therapy. Cancer $35: 1517 \sim 1524$, 1975.

5 ) Mulholland MW, Megallanes F, et al : Aggressive surgical therapy after irradiation failure in treatment of cancer of the oral tongue. Arch Surg 119:394 399, 1984.

6 ）藤谷哲造, 服部 浩, 他：舌癌の罰部転移に関す 万臨床的検討. 耳鼻臨床 $70: 939 \sim 946,1977$.

7 ) Leipzig B, Cummings $\mathrm{CW}$, et al : Carcinoma of the anterior tongue. Ann Otol 91:94 97, 1982.

8 ) Vermund H, Brennhovd IO, et al : Squamouscell carcinoma of the tongue: Preoerative interstitial radium and external irradiation. Part I : Local and regional control. Radiology |5|: 499 503, 1984,

9 ）熊倉姜美: 舌切除後の構音機能に関する研究, 舌 癌60症例の検討. 音声言語医学 $26: 224 \sim 235$, 1985.

10) Lehman RH, Cox JD, et al : Recurrence patterns by treatment modality of carcinomas of the floor of the mouth and oral tongue. Am J Otolaryngol $3: 174 \sim 181,1982$.
11) Holm LE, Lundquist PG, et al : Combined preoperative radiotherapy and surgery in the treatment of carcinoma of the anterior twothirds of the tongue. Laryngoscope $93: 792$ $\sim 796,1983$

12) Decroix $Y$ and Ghossein NA : Experience of the Curie Institute in treatment of cancer of the mobile tongue: II. Mangement of the neck nodes. Cancer $47: 503 \sim 508,1981$.

13) Horiuchi $J$ and Adachi $T$ : Some considerations on radiation therapy of tongue cancer. Cancer $28:$ 335 339, 1971.

14) Million RR : Elective neck irradiation for TxNO squamous carcinona of the oral tongue and floor of mouth. Cancer $34: 149 \sim 155$, 1974.

15) Fu KK, Ray JW, et al : External and interstitial radiation therapy of carcinoma of the oral tongue. Am J Roentgenol 126:107 115, 1976.

16) Beavfr B, Ferrara J, et al : Primary procedure in carcinoma of the tongue: Local resection versus combined local resection and radical neck dissection. Curr Surg 39:405 407, 1892.

17）永本 浩, 小笠原宽, 雲井健雄：舌癌を発症した Zinsser-Cole-Engman 症候群の 1 例. 兵医大会 誌 $8: 117 \sim 123,1983$.

$$
\left(\begin{array}{l}
\text { 別刷請求先 : 小笠原 寛 } \\
\text { T663 西宮市武庫川町 } 1-1 \\
\text { 兵庫医科大学耳渔咽㗱科学教室 }
\end{array}\right)
$$

